\title{
Improvement of Impaired Memory in Mice by Taurine
}

\author{
Bhupinder P.S. Vohra ${ }^{\dagger}$ and Xiang Hui \\ Department of Biotechnology, School of Life Sciences \\ Sun-Yat-Sen University, Guangzhou, China-510 275
}

\section{SUMMARY}

Taurine was extracted from Pegasus laternarius Cuvier to study its effects on learning and memory in mice. Mice were treated with different doses of taurine $(10 \mathrm{mg} / \mathrm{kg}, 20 \mathrm{mg} / \mathrm{kg}, 40 \mathrm{mg} / \mathrm{kg})$. The mice were treated with various chemical agents (pentobarbital, cycloheximide, sodium nitrite, alcohol) to disrupt the normal memory process. We measured the effect of taurine on step-down latency (SDL) and escape latency (EL) in a passive avoidance task after 10 or 30 days. Treatment with taurine alone did not change either SDL or EL. Taurine protected mice from the memory disruption induced by alcohol, pentobarbital, sodium nitrite, and cycloheximide but had no obvious effect on motor coordination, exploratory activity, or locomotor activity as measured using the rota-rod test and the hole board test. We conclude that taurine can be effective in attenuating the amnesia produced by alcohol, pentobarbital, cycloheximide, and sodium nitrite without compromising the behavioral aspects of the animals tested.

\section{KEYWORDS}

taurine, Pegasus laternarius Cuvier, learning, memory

\footnotetext{
${ }^{\top}$ Corresponding author; present address:

Department of Neurology, Box 295

Univ. of Minnesota, 420 Delaware St. SE

Minneapolis, MN 55455, USA

tel: +612 624 1462; fax: +6126262639

e-mail: Vohra001@tc.umn.edu
}

\section{INTRODUCTION}

Taurine is a physiologically ancient compound that has been implicated in diverse physiological functions and is known to play an important role in neural function (Huxtable 1989, 1992). Taurine levels are regulated by the blood-brain barrier, but this control is independent of taurine concentrations in the blood and the brain stem, where high taurine levels remain constant (Tsuji \& Tamai, 1996). Clinical and electroencephalographic observations and psychological tests have revealed taurine's beneficial effects on various neuronal functions (Montanini \& Gasco, 1974). Taurine has shown positive effects in various free-radical-associated pathological conditions (Man'Kovs'Ka et al., 1998; You \& Chang, 1998; Son et al., 1998). Free radicals are implicated in the degeneration of cholinergic neurons in Alzheimer's and in normal aging brain tissue (Ceballos et al., 1990; Michiels et al., 1994). Taurine protects NMDA receptors from kainic acid-induced oxidative stress (Huxtable, 1992) and can play a very important role in memory function as it modulates NMDA receptors (Saransaari \& Oja, 1993). Taurine and its various compounds are beneficial in a multitude of memory functions (Balazs \& Telegdy, 1988; Liljequist \& Winblad, 1998). It is also known that natural taurine from Pegasus laternarius Cuvier is used as a traditional cure for senile disorders in China.

All these facts manifest the importance of studying the protective effects of taurine against amnesia-inducing treatments and how taurine alone modulates learning processes. Therefore, 
mice were exposed to various amnesia inducers to study the attenuation of amnesia by taurine. To measure this, mice were subjected to the passive avoidance task. Step down (SDL) and escape latency (EL) measurements were taken together in normal and in memory-disrupted mice to eliminate the unspecific effect of the test drugs (Zhu \& Tang, 1988). Furthermore, we studied the effect of taurine on locomotor activity, exploratory activity, and motor coordination in such mice.

\section{EXPERIMENTAL}

Balb/c mice, weighing from 20 to $25 \mathrm{~g}$, were randomly assigned to 8 groups of 114 mice each. The mice were treated intragastrically with taurine, which was dissolved in distilled water at three different dosages: $10 \mathrm{mg} / \mathrm{kg}$ (T1), $20 \mathrm{mg} / \mathrm{kg}$ (T2), $40 \mathrm{mg} / \mathrm{kg}$ (T3), or with distilled water (control) for either $10 \mathrm{~d}$ or $30 \mathrm{~d}$.

The motor activity level was measured before the mice were subjected to amnesia-inducing agents and behavioral tests. All experiments were carried out at the same time of day and under identical conditions.

\section{Motor coordination (Rota-Rod Test)}

The apparatus consisted of a base platform and a rotating rod $(3 \mathrm{~cm}$ in diameter) with a nonslippery surface. The rod was placed at a height of $15 \mathrm{~cm}$ above the base, which was $30 \mathrm{~cm}$ long and divided into 5 equal sections by 6 disks. Thus, 5 mice were tested simultaneously with a rotating speed of $16 \mathrm{rpm}$. The integrity of motor coordination was assessed on the basis of the number of falls from the rod in $30 \mathrm{sec}$ (Ghelardini et al., 1998). In another set of experiments, both control and taurine-treated animals were fed with $40 \%$ alcohol $(0.1 \mathrm{ml} / 10 \mathrm{~g})$ and then tested on the rota- rod test to examine the effect of taurine on alcohol induced motor coordination disturbance.

\section{Exploratory and locomotor activity (Hole Board Test)}

The hole board test consisted of a $40-\mathrm{cm}$ square plane with 16 cylindrical holes distributed in a grid-like manner. Mice were placed, one by one, in the center of the board and allowed to move freely; the movements of the animals (locomotor activity, counts in $10 \mathrm{~min}$ in different plane) were recorded. The exploratory activity was calculated as the number of times a mouse touched the hole with its snout (Ghelardini et al., 1998).

\section{Behavioral activity (Passive Avoidance Task}

A wooden box was separated into four equal squared chambers by plastic planks. Each chamber had a rubber platform $(8 \times 8 \times 0.5 \mathrm{~cm})$ in the right corner. An electric grid was present on the floor of each chamber. The procedure consisted of three phases:

1. Adaptation: The mice were habituated to the compartments for $300 \mathrm{sec}$.

2. Training: The mice were trained to remain on a rubber platform. When the mice moved away from the safety zone, they were exposed to a continuous electric shock $(0.8 \mathrm{~mA})$ from the grid floor.

3. Retention test: The mice were tested for the passive avoidance task after $24 \mathrm{~h}$ training. Individual mice were placed on the rubber platform and the time that the animal spent on the platform was recorded as the step down latency. The animals were placed on the grid floor and were exposed to electric current, the time required by the animal to return back to the rubber platform was recorded as the escape latency. 


\section{Behavioral experiments}

The administration schedule for sodium pentobarbital, sodium nitrite, and alcohol was chosen on the basis of preliminary experiments, in which the time course for their maximum action was determined; the cycloheximide time schedule was based on previous studies (Zhu \& Tang, 1988).

Experiment 1: Untreated control and taurinetreated mice ( 29 per group) were subjected to the passive avoidance task. SDL and EL were recorded for each mouse.

Experiment 2: Untreated control and taurinetreated mice (19 per group) were injected with sodium pentobarbital ( $15 \mathrm{mg} / \mathrm{kg}$, i.p.) $30 \mathrm{~min}$ before training. Mice were subjected to the retention test $24 \mathrm{~h}$ after training.

Experiment 3: Immediately after training, untreated control and taurine-treated mice (16 per group) were injected (s.c.) with $120 \mathrm{mg} / \mathrm{kg}$ sodium nitrite and subjected to the retention test $24 \mathrm{~h}$ later.

Experiment 4: Immediately after training, untreated control and taurine-treated mice (16 per group) were injected (s.c.) with $150 \mathrm{mg} / \mathrm{kg}$ cycloheximide and subjected to the retention test $24 \mathrm{~h}$ later.

Experiment 5: Thirty min before the retention test, untreated control and taurine treated mice (19 per group) received $0.1 \mathrm{~mL} / 10 \mathrm{~g} 40 \%$ ethyl alcohol orally.

\section{Statistical analysis}

All experimental results are given as mean \pm SD. Analysis of variance (ANOVA) was followed by Fisher's post-hoc comparison and was used to verify the significance between two means. $P$ values $<0.05$ were considered significant. The data were analyzed after the two longest and the two shortest latencies in each group were eliminated.

\section{RESULTS}

\section{Effect of taurine on mouse rota-rod and hole} board tests

Taurine elicited modulatory effects on the cognitive process without changing either gross behavioral or motor coordination and exploratory activity as revealed by the rota-rod test. Even the highest administered dose of taurine did not increase or decrease the number of falls from the rotating rod in comparison with control animals. However, taurine effectively corrected the impaired motor coordination in alcohol-animals $(p<0.05)$ (Table 1).

\section{Effect of taurine on learning and memory}

After 10-days or 30-days of treatment with taurine, no significant change was observed in either SDL or EL of either group.

\section{Effect of amnesia-inducing treatments}

Treatment of 10-d, non-taurine treated mice with sodium pentobarbital $(15 \mathrm{mg} / \mathrm{kg}$, i.p.) $30 \mathrm{~min}$ before training resulted in a significant decrease $(\mathrm{F}=299.284, \mathrm{P}<0.0001)$ in $\mathrm{SDL}$ and a significant increase in $\mathrm{EL}(\mathrm{F}=130.102, \mathrm{P}<0.0001)$. In the $30-\mathrm{d}$ non-taurine treated control, sodium pentobarbital also significantly reduced SDL $(\mathrm{F}=120.532, \mathrm{P}<$ $0.0001)$ and increased $\mathrm{EL}(\mathrm{F}=59.881, \mathrm{P}<0.0001)$.

Treatment with $120 \mathrm{mg} / \mathrm{kg}$ sodium nitrite (s.c.) immediately after training reduced SDL in both $10-\mathrm{d}(\mathrm{F}=232.323, \mathrm{P}<0.0001)$ and $30-\mathrm{d}(\mathrm{F}=239.839$, $\mathrm{P}<0.0001$ ) control groups and increased EL in both $10-\mathrm{d}(\mathrm{F}=121.221, \mathrm{P}<0.0001)$ and $30-\mathrm{d}(\mathrm{F}=65.396$, $\mathrm{P}<0.0001$ ) control groups.

Immediately after training, exposure to 150 $\mathrm{mg} / \mathrm{kg}$ cycloheximide (s.c.) significantly shortened 
TABLE 1

Effect of taurine treatment on motor coordination (rota-rod test) in mice receiving $40 \%$ ethanol or water

\begin{tabular}{|c|c|c|c|c|c|}
\hline \multirow{2}{*}{ Treatment } & \multirow{2}{*}{$\begin{array}{c}\text { Dosage } \\
\text { (mg/kg b.w.) }\end{array}$} & \multicolumn{4}{|c|}{ Number of falls* } \\
\cline { 3 - 6 } & & \multicolumn{2}{|c|}{ 10-days } & \multicolumn{2}{c|}{ 30-days } \\
\cline { 3 - 6 } & & Without alcohol & With alcohol & Without alcohol & With alcohol \\
\hline \multirow{2}{*}{$\begin{array}{c}\text { Distilled } \mathrm{H}_{2} \mathrm{O} \\
\text { (control) }\end{array}$} & 0 & $3.6 \pm 0.9$ & $5.6 \pm 0.8^{\dagger}$ & $3.2 \pm 0.4$ & $5.9 \pm 0.9^{\dagger}$ \\
\hline \multirow{3}{*}{ Taurine } & 10 & $3.2 \pm 0.6$ & $4.1 \pm 0.3$ & $3.5 \pm 0.3$ & $4.4 \pm 0.5$ \\
\cline { 2 - 6 } & 20 & $3.0 \pm 0.5$ & $3.5 \pm 0.4^{\ddagger}$ & $2.9 \pm 0.4$ & $3.7 \pm 0.4^{\ddagger}$ \\
\cline { 2 - 6 } & 40 & $3.3 \pm 0.3$ & $3.3 \pm 0.2^{\ddagger}$ & $3.9 \pm 0.6$ & $3.7 \pm 0.5^{\ddagger}$ \\
\hline
\end{tabular}

*Values are the number of falls in 30 seconds \pm SD of 20 animals

${ }^{\dagger}$ Values are significantly different $(\mathrm{P}<0.05)$ from untreated control group without alcohol

${ }^{\ddagger}$ Values are significantly different $(\mathrm{P}<0.05)$ from untreated control group fed alcohol

SDL in both 10-d $(\mathrm{F}=241.509, \mathrm{P}<0.0001)$ and $30-\mathrm{d}$ $(\mathrm{F}=160.472, \mathrm{P}<0.0001)$ control groups. Cycloheximide increased $\mathrm{EL}$ in both $10-\mathrm{d}(\mathrm{F}=98.57, \mathrm{P}<$ $0.0001)$ and $30-\mathrm{d}(\mathrm{F}=35.714, \mathrm{P}<0.0001)$ control groups.

Oral treatment with $40 \%$ ethyl alcohol $(0.1 \mathrm{ml} /$ $10 \mathrm{~g}) 30 \mathrm{~min}$ before the retention test significantly reduced $\mathrm{SDL}$ in both $10-\mathrm{d}(\mathrm{F}=165.517, \mathrm{P}<0.0001)$ and $30-\mathrm{d}(\mathrm{F}=261.249, \mathrm{P}<0.0001)$ control groups, but significantly increased EL in both $10-\mathrm{d}(\mathrm{F}=$ 130.102, $\mathrm{P}<0.0001)$ and $30-\mathrm{d}(\mathrm{F}=97.575, \mathrm{P}<0.0001)$ control groups.

\section{Anti-amnesia inducing effect of taurine}

Sodium pentobarbital. Taurine treatment protected the animals from the effect of sodium pentobarbital in all treatment groups( Figs. 1 to 4). SDL was significantly higher in all groups receiving combined taurine+sodium pentobarbital at doses of $10 \mathrm{mg} / \mathrm{kg}$ taurine $(\mathrm{F}=9.450, \mathrm{P}=0.0047)$; $20 \mathrm{mg} / \mathrm{kg}$ taurine $(\mathrm{F}=32.712, \mathrm{P}<0.0001)$; or 40 $\mathrm{mg} / \mathrm{kg}$ taurine $(\mathrm{F}=70.144, \mathrm{P}<0.0001)$ than that of mice receiving sodium pentobarbital alone. Taurine treatment was also helpful in restoring normal EL in all treatment groups: $10 \mathrm{mg} / \mathrm{kg}(\mathrm{F}=10.216$, $\mathrm{P}=0.0034), 20 \mathrm{mg} / \mathrm{kg}(\mathrm{F}=9.539, \mathrm{P}=0.0045), 40 \mathrm{mg} / \mathrm{kg}$ $(\mathrm{F}=66.360, \mathrm{P}<0.0001)$.

The 30-day taurine treatment at doses of 10 $\mathrm{mg} / \mathrm{kg} \quad(\mathrm{F}=9.205, \mathrm{P}=0.0052), 20 \mathrm{mg} / \mathrm{kg} \quad(\mathrm{F}=119.414$, $\mathrm{P}<0.0001)$, or $40 \mathrm{mg} / \mathrm{kg} \quad(\mathrm{F}=217.728, \mathrm{P}<0.0001)$ was useful in overcoming the SDL-decreasing effect of sodium pentobarbital. Taurine treatment at $20 \mathrm{mg} / \mathrm{kg}$ was effective $(\mathrm{F}=20.811, \mathrm{P}<0.0001)$ in attenuating the increased EL that is elicited by sodium pentobarbital. Likewise, a dose of 40 $\mathrm{mg} / \mathrm{kg}$ taurine also had a significant protective effect $(\mathrm{F}=41.710, \mathrm{P}<0.0001)$.

Sodium nitrite. Ten days of taurine treatment attenuated the effect of sodium nitrite on SDL and was helpful in significantly preventing a fall in SDL values: $10 \mathrm{mg} / \mathrm{kg}$ taurine $(\mathrm{F}=15.548, \mathrm{P}=0.0007)$; $20 \mathrm{mg} / \mathrm{kg}$ taurine $(\mathrm{F}=17.01, \mathrm{P}=0.0004) ; 40 \mathrm{mg} / \mathrm{kg}$ $(\mathrm{F}=46.406, \mathrm{P}<0.0001)$. All taurine-treated groups had significantly higher EL $10 \mathrm{mg} / \mathrm{kg}$ taurine $(\mathrm{F}=$ 26.174, $\mathrm{P}<0.0001) ; 20 \mathrm{mg} / \mathrm{kg}$ taurine $(\mathrm{F}=30.529$, 


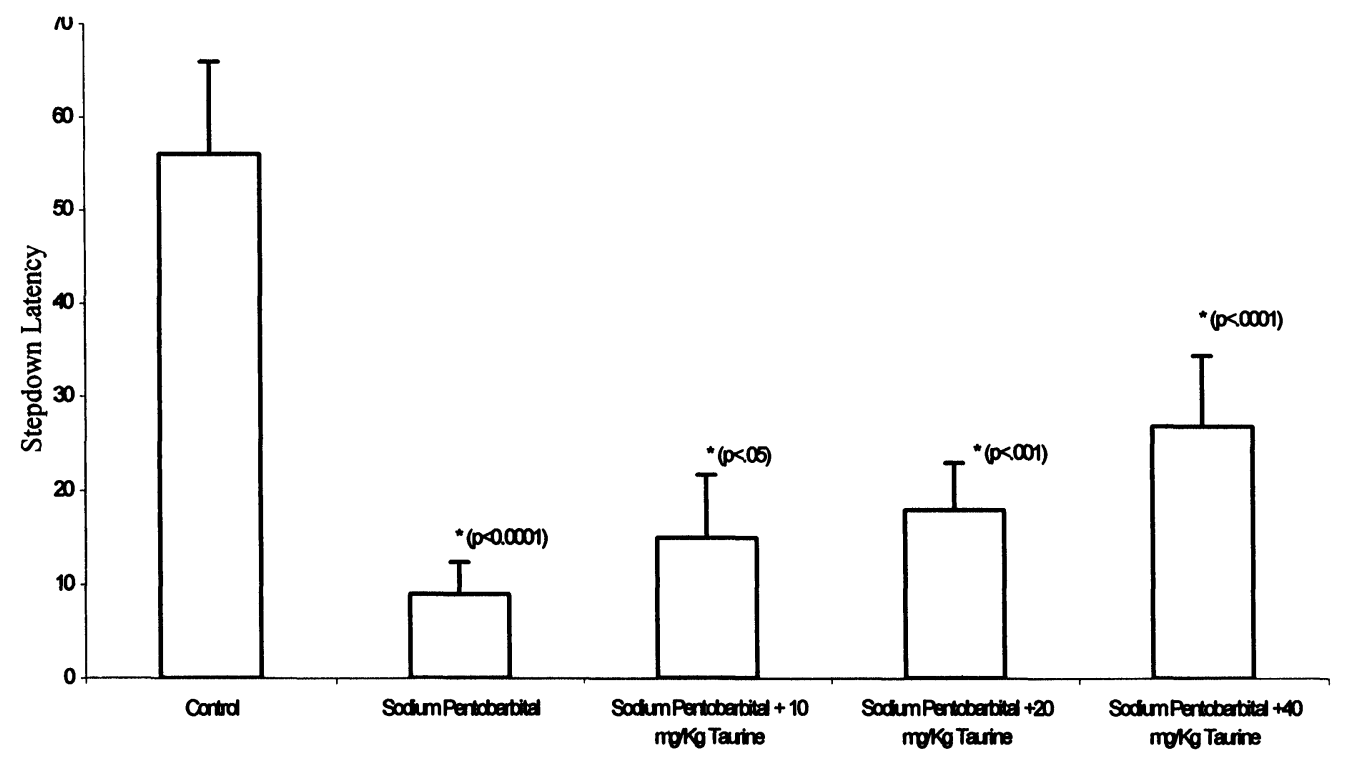

\# significantly different from controls, ${ }^{*}$ significantly different from the sodium pentobarbital treated mice

Fig. 1: Effect of 10 days of taurine treatment on stepdown latency in sodium pentobarbital-treated mice

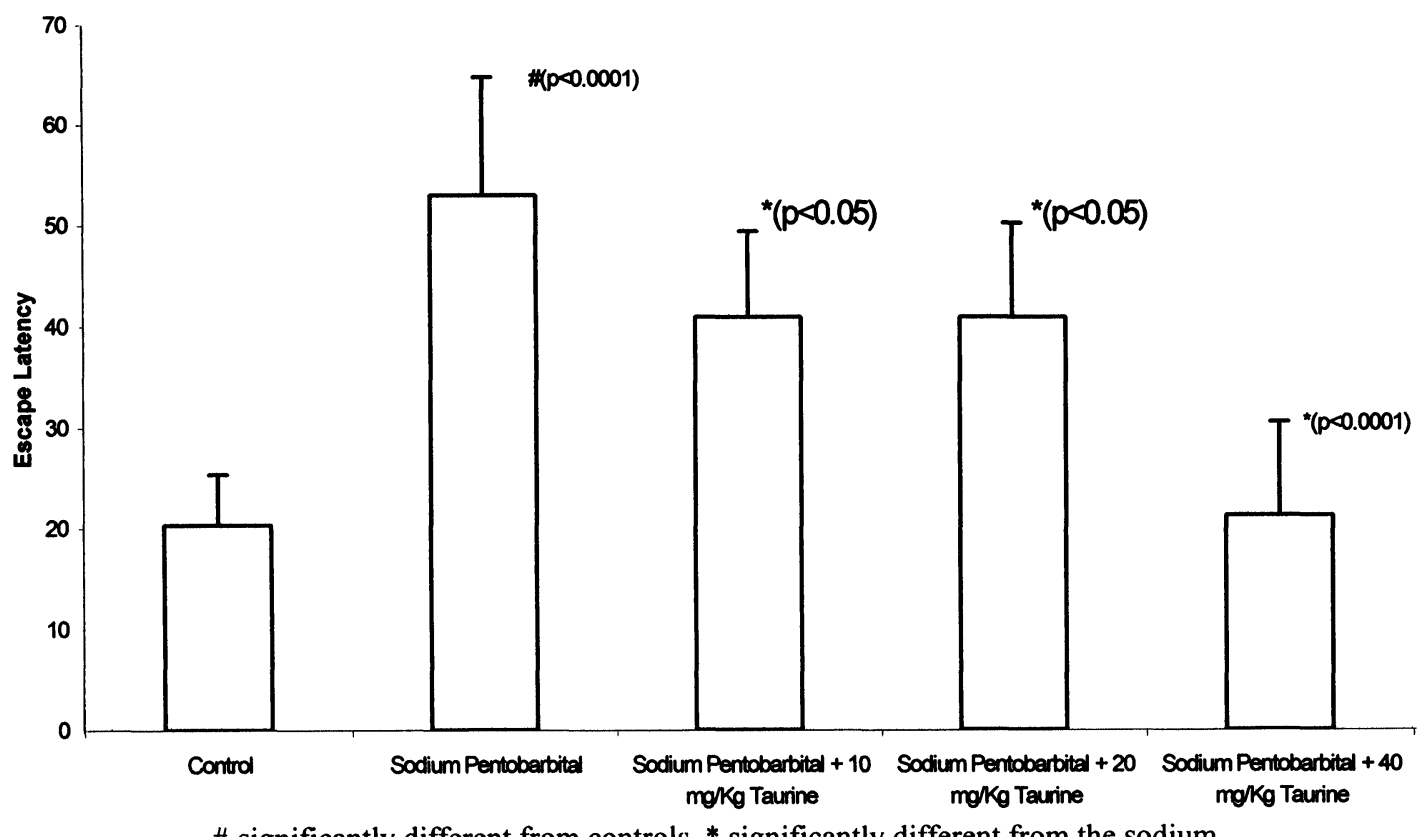

\# significantly different from controls, * significantly different from the sodium pentobarbital treated mice

Fig. 2: Effect of 10 days of taurine treatment on escape latency of sodium pentobarbital-treated mice 


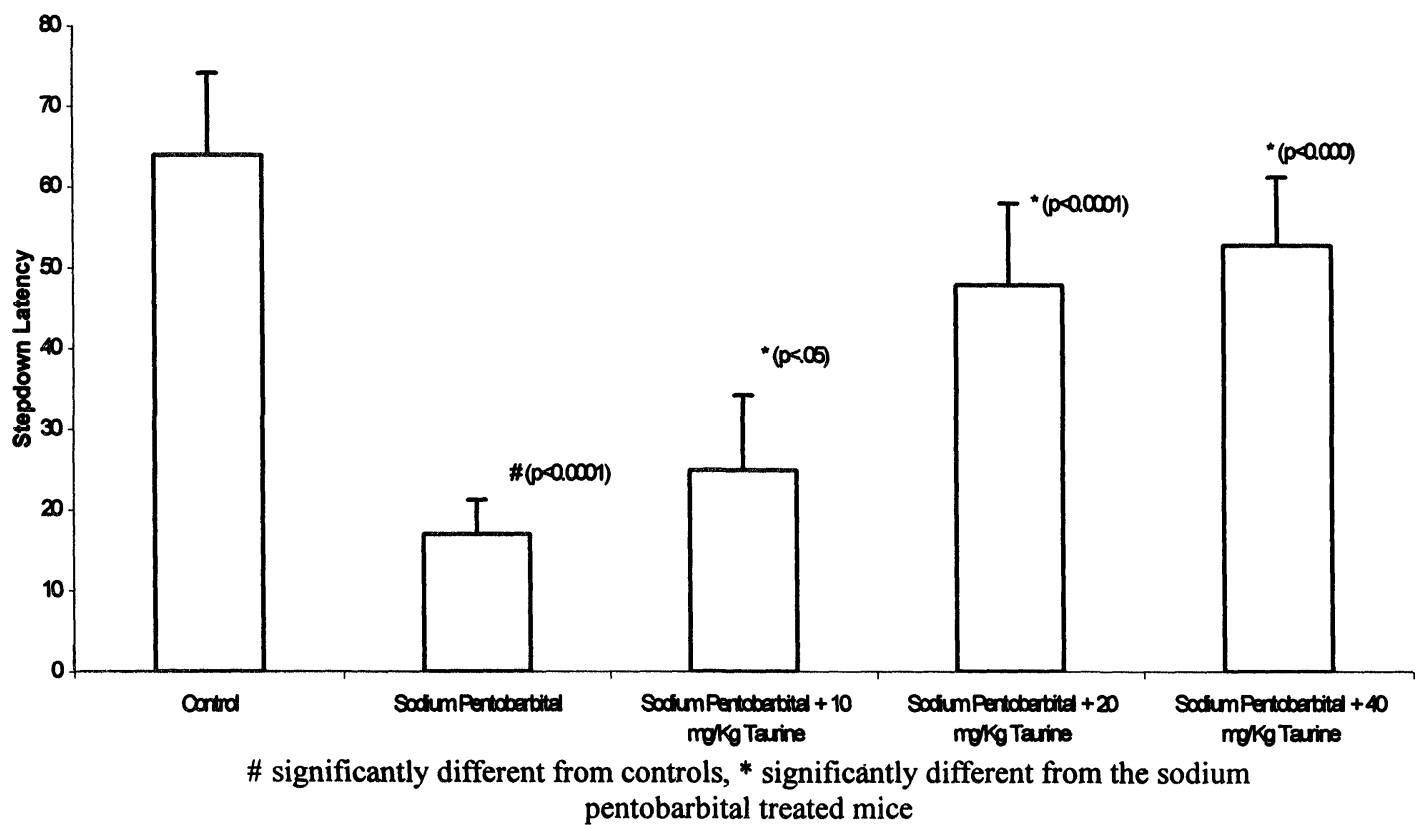

Fig. 3: Effect of 30 days of taurine treatment on stepdown latency in sodium pentobarbital-treated mice

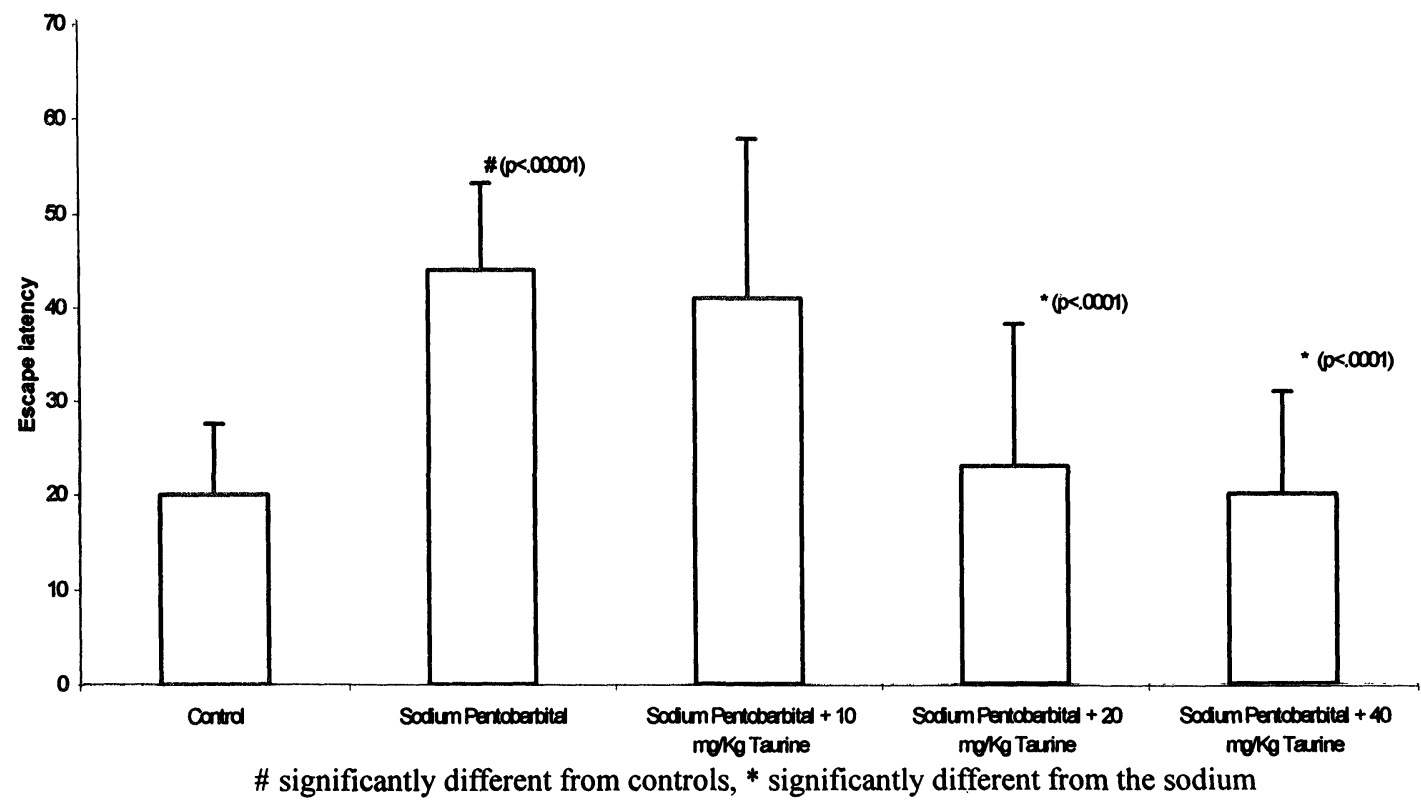

pentobarbital treated mice

Fig. 4: Effect of 30 days of taurine treatment on escape latency in sodium pentobarbital-treated mice 
$\mathrm{P}<0.0001) ; 40 \mathrm{mg} / \mathrm{kg}$ taurine $(\mathrm{F}=66.054, \mathrm{P}<0.0001)$ in comparison with the group of animals treated with sodium nitrate alone (Figs. 5, 6). Thirty days of taurine treatment was equally effective in circumventing the ill effects of sodium nitrite on SDL in all treatment groups: $10 \mathrm{mg} / \mathrm{kg}$ taurine $(\mathrm{F}=34.856$, $\mathrm{P}<0.0001) ; 20 \mathrm{mg} / \mathrm{kg}$ taurine $(\mathrm{F}=46.311, \mathrm{P}<0.0001)$; $40 \mathrm{mg} / \mathrm{kg}$ taurine $(F=58.292, P<0.0001)$. Similar effects were observed on the EL of taurine-treated groups: $10 \mathrm{mg} / \mathrm{kg}$ taurine $(\mathrm{F}=36.220, \mathrm{P}<0.0001)$; $20 \mathrm{mg} / \mathrm{kg}$ taurine $(\mathrm{F}=34.998, \mathrm{P}<0.0001)$; and 40 $\mathrm{mg} / \mathrm{kg}$ taurine-treated $(\mathrm{F}=36.997, \mathrm{P}<0.0001)$ groups had significantly higher EL than did the group of animals treated with sodium nitrite alone (Figs. 7, 8).

Cycloheximide. After 10 days, taurine-treated animals receiving cycloheximide had significantly higher SDL in comparison with animals given cycloheximide alone: $(20 \mathrm{mg} / \mathrm{kg}$ taurine+ cycloheximide: $\mathrm{F}=95.370, \mathrm{P}<0.0001 ; 40 \mathrm{mg} / \mathrm{kg}$ taurine + cycloheximide: $\mathrm{F}=145.348, \mathrm{P}<0.0001$ ) (Figs. 9, 10). Thirty days of taurine treatment at doses of $20 \mathrm{mg}$ / $\mathrm{kg}(\mathrm{F}=186.411, \mathrm{P}<0.0001)$ and $40 \mathrm{mg} / \mathrm{kg}(\mathrm{F}=$
303.269, $\mathrm{P}<0.0001$ ) taurine+cycloheximide also significantly raised SDL when compared with groups given cycloheximide alone. The two higher doses of taurine ( 20 and $40 \mathrm{mg} / \mathrm{kg}$ ) were effective in significantly lengthening the EL after $10 \mathrm{~d}(\mathrm{~F}=$ $35.200, \mathrm{P}<0.0001 ; \mathrm{F}=53.935, \mathrm{P}<0.0001$, respectively) and $30 \mathrm{~d}$ of treatment $(\mathrm{F}=27.030, \mathrm{P}<0.0001$; $\mathrm{F}=31.183, \mathrm{P}<0.0001$, respectively) (Figs. 11, 12).

Ethyl alcohol. Treatment with taurine for 10 days significantly raised SDL in groups receiving $20 \mathrm{mg} / \mathrm{kg}$ taurine+alcohol $(\mathrm{F}=165.705, \mathrm{P}<0.0001)$ or $40 \mathrm{mg} / \mathrm{kg}$ taurine+alcohol $(\mathrm{F}=223.271, \mathrm{P}<0.0001)$ above that in groups of animals treated with alcohol alone. EL was also significantly higher in groups receiving $10 \mathrm{mg} / \mathrm{kg}$ taurine+alcohol $(\mathrm{F}=25.294$, $\mathrm{P}<0.0001), 20 \mathrm{mg} / \mathrm{kg}$ taurine+alcohol $(\mathrm{F}=52.790$, $\mathrm{P}<0.0001)$, or $40 \mathrm{mg} / \mathrm{kg} \quad(\mathrm{F}=65.654, \mathrm{P}<0.0001)$ (Figs. 13, 14). Interestingly, after 30 days of taurine treatment, only one dose $(40 \mathrm{mg} / \mathrm{kg}$ taurine+alcohol) elicited significantly higher SDL $(\mathrm{F}=22.520, \mathrm{P}<$ $0.0001)$ and lower EL $(F=100.905, P<0.0001)$ than that in mice receiving alcohol alone (Fig. 15, 16).

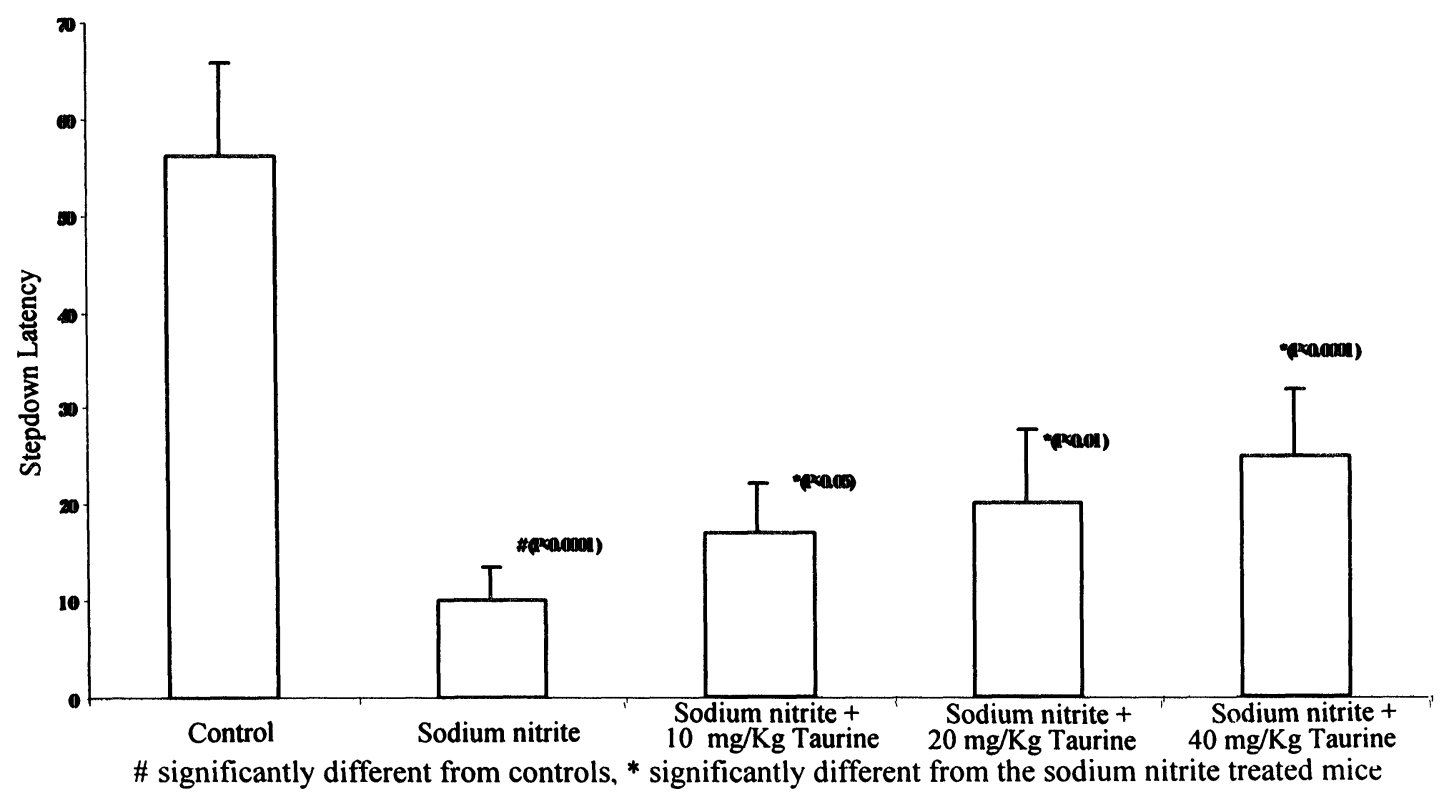

Fig. 5: Effect of 10 days of taurine treatment on stepdown latency in sodium nitrite-treated mice 


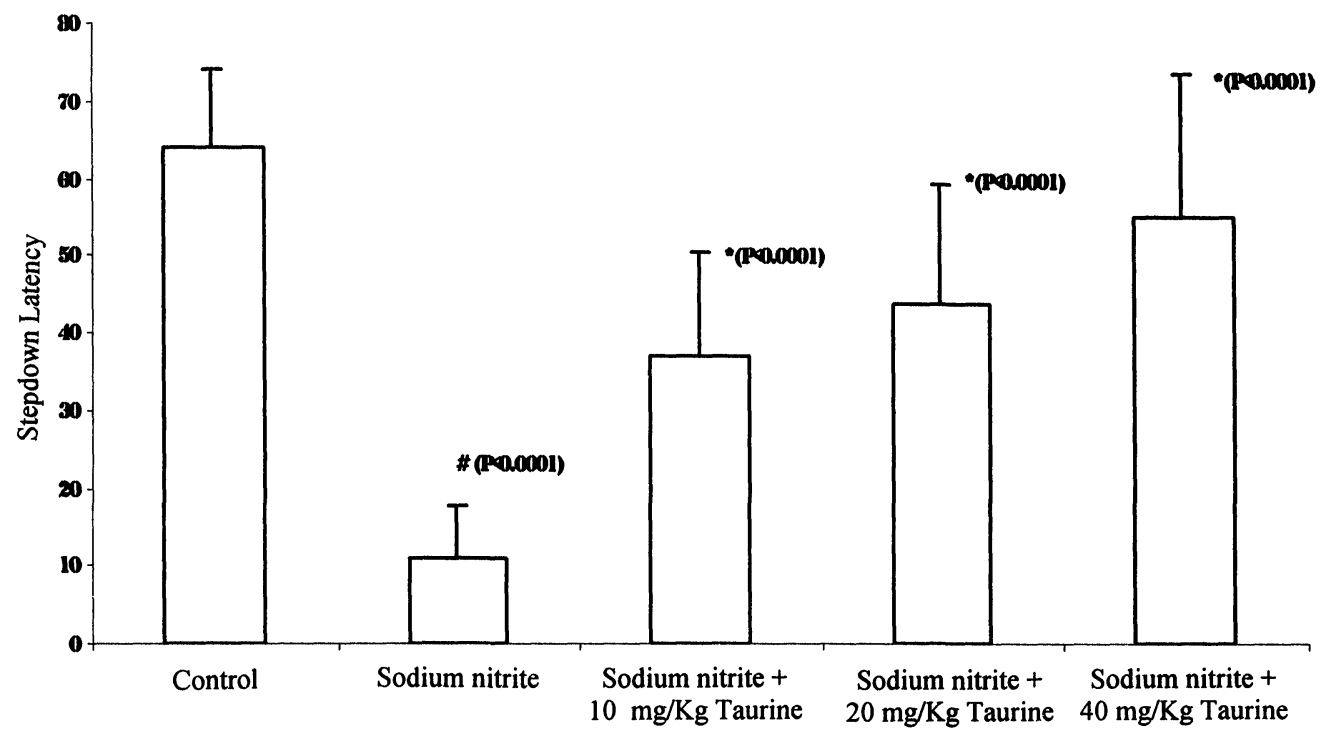

\# significantly different from controls, ${ }^{*}$ significantly different from the sodium nitrite treated mice

Fig. 6: Effect of 10 days of taurine treatment on stepdown latency of sodium nitrite-treated mice

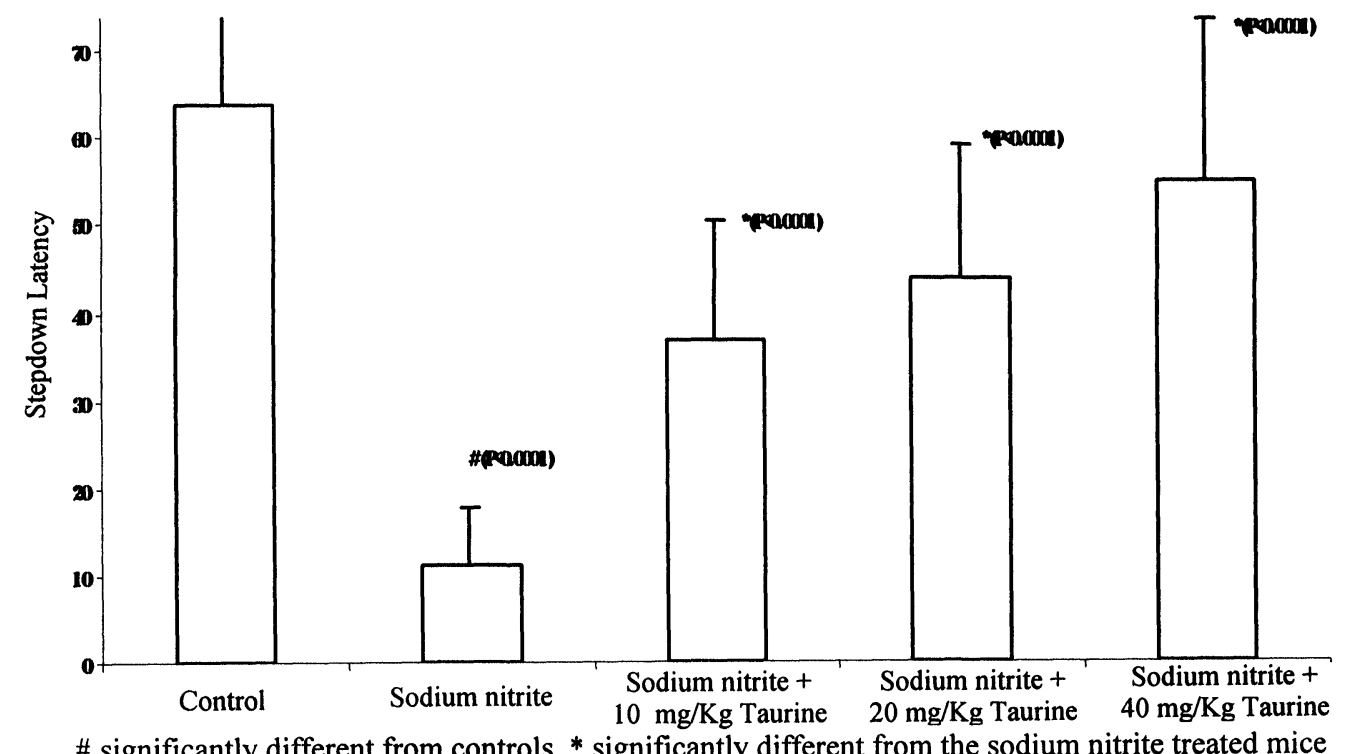

Fig. 7: Effect of 30 days of taurine treatment on stepdown latency in sodium nitrite-treated mice 


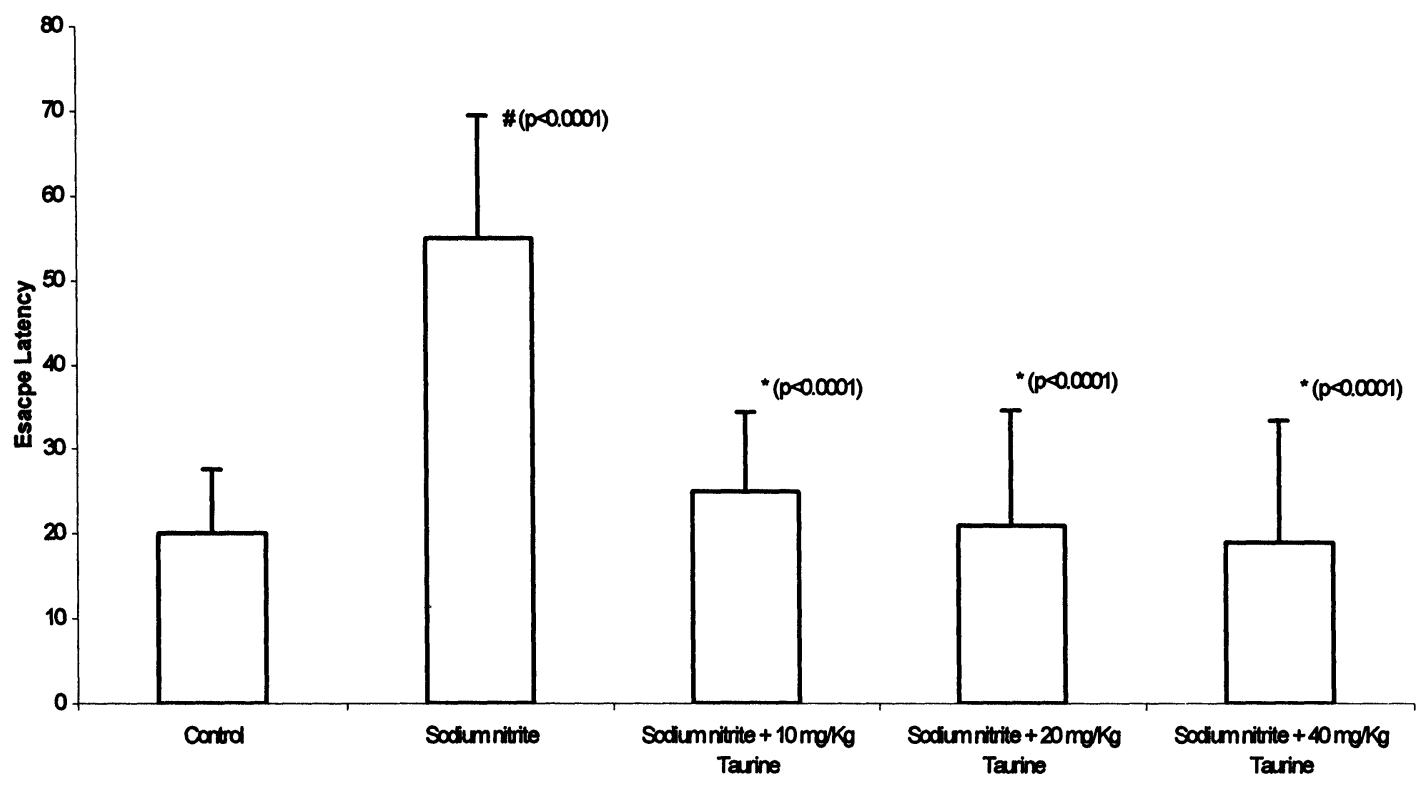

\# significantly different from controls, ${ }^{*}$ significantly different from the sodium nitrite treated mice

Fig. 8: Effect of 30 days of taurine treatment on escape latency in sodium nitrite-treated mice

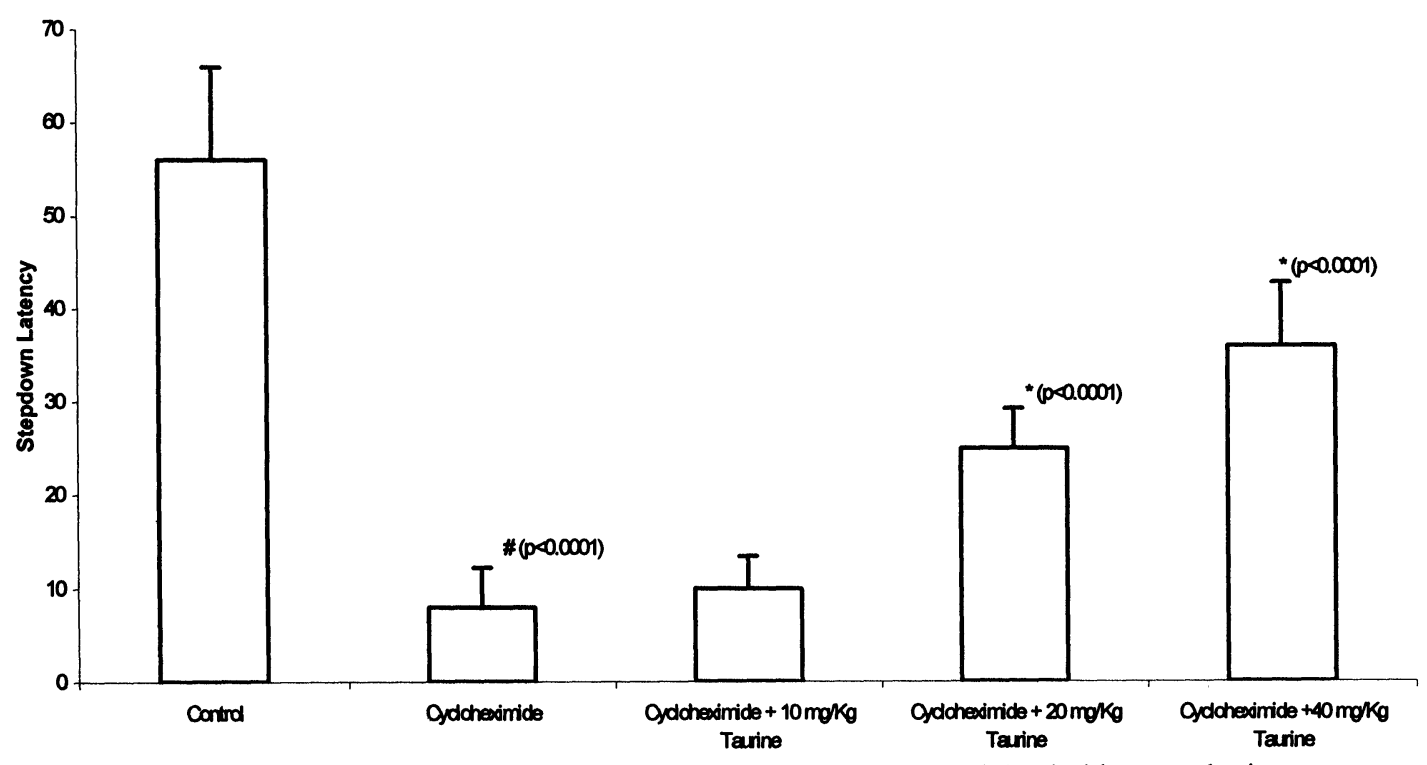

\# significantly different from controls, ${ }^{*}$ significantly different from cycloheximide treated mice

Fig. 9: Effect of 10 days of taurine treatment on stepdown latency in cycloheximide-treated mice 


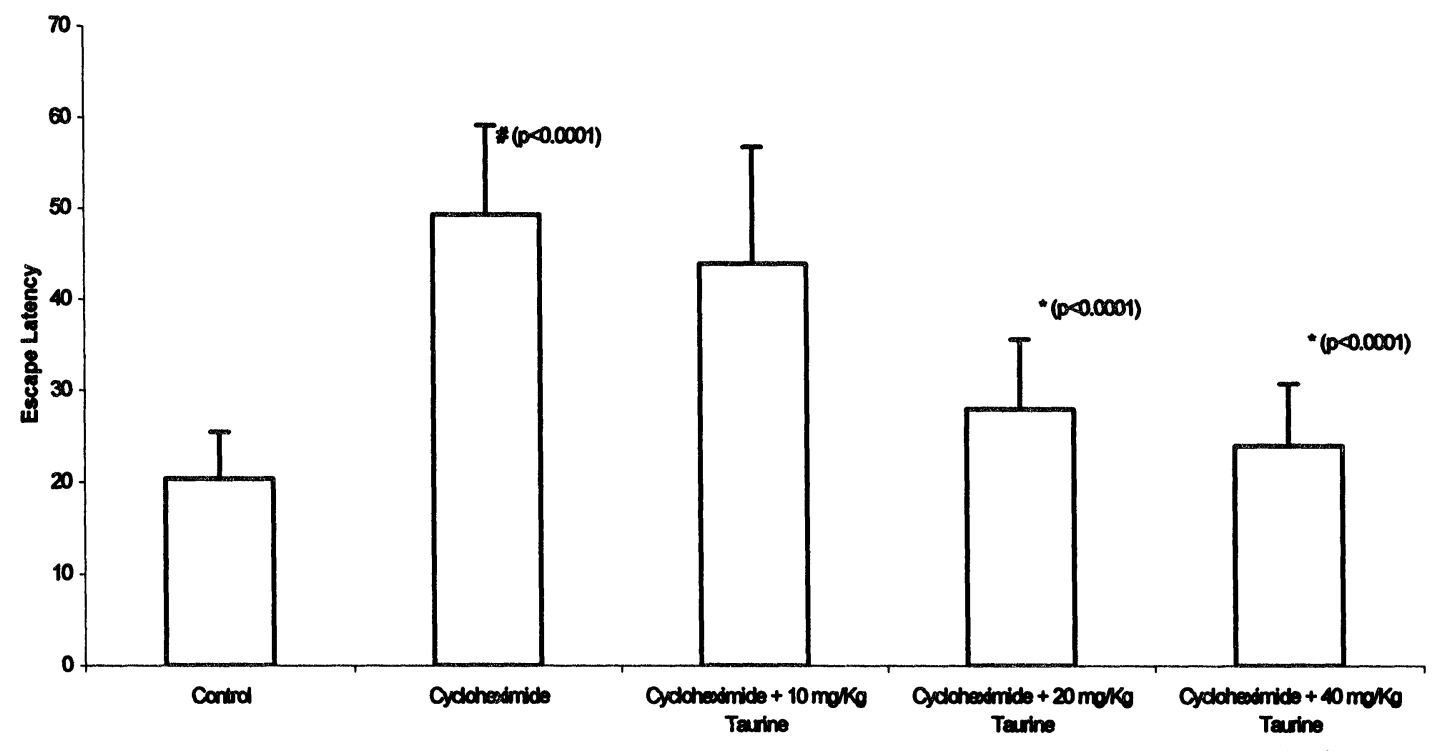

\# significantly different from controls, * significantly different from cycloheximide treated mice

Fig. 10: Effect of 10 days of taurine treatment on escape latency in cycloheximide-treated mice

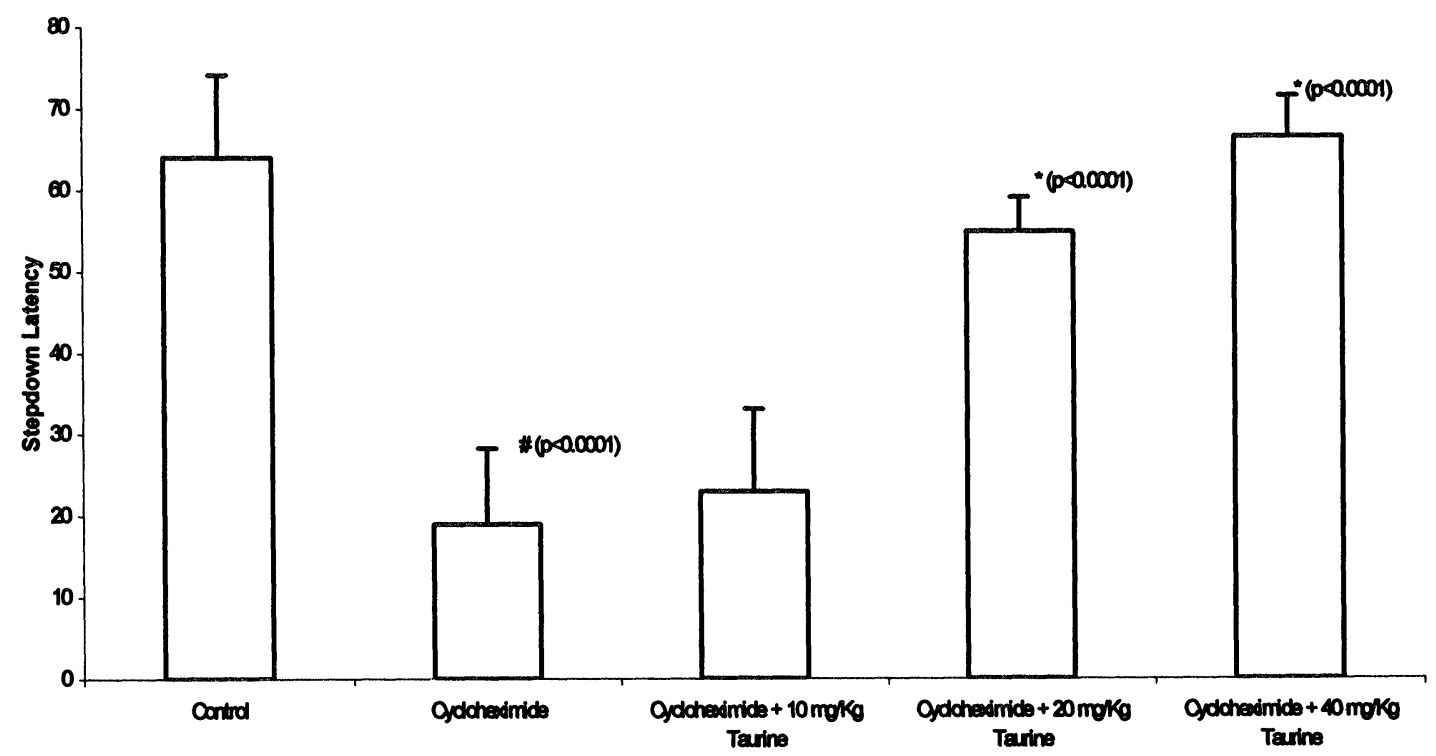

\# significantly different from controls, ${ }^{*}$ significantly different from cycloheximide treated mice

Fig. 11: Effect of 30 days of taurine treatment on stepdown latency in cycloheximide-treated mice 


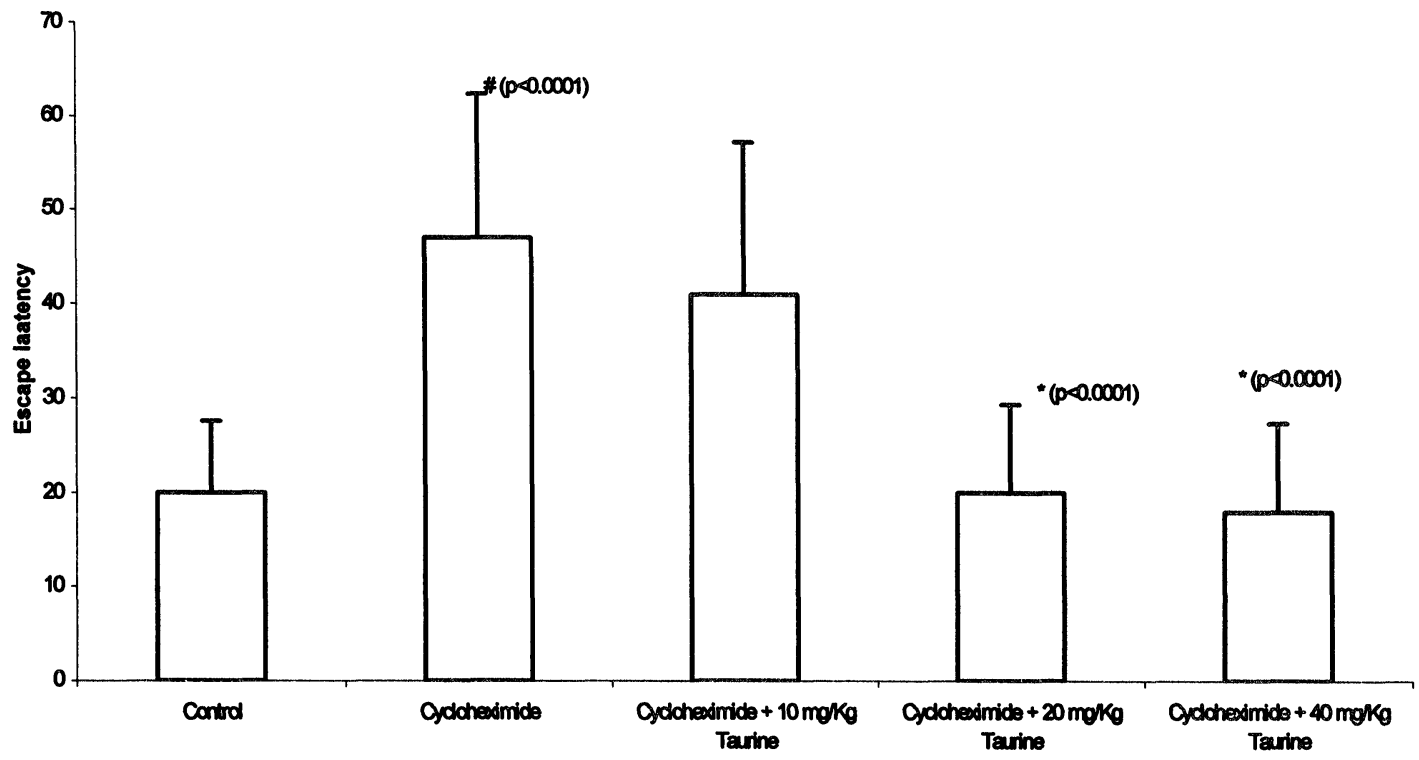

\# significantly different from controls, * significantly different from cycloheximide treated mice

Fig. 12: Effect of 30 days of taurine treatment on escape latency in cycloheximide-treated mice

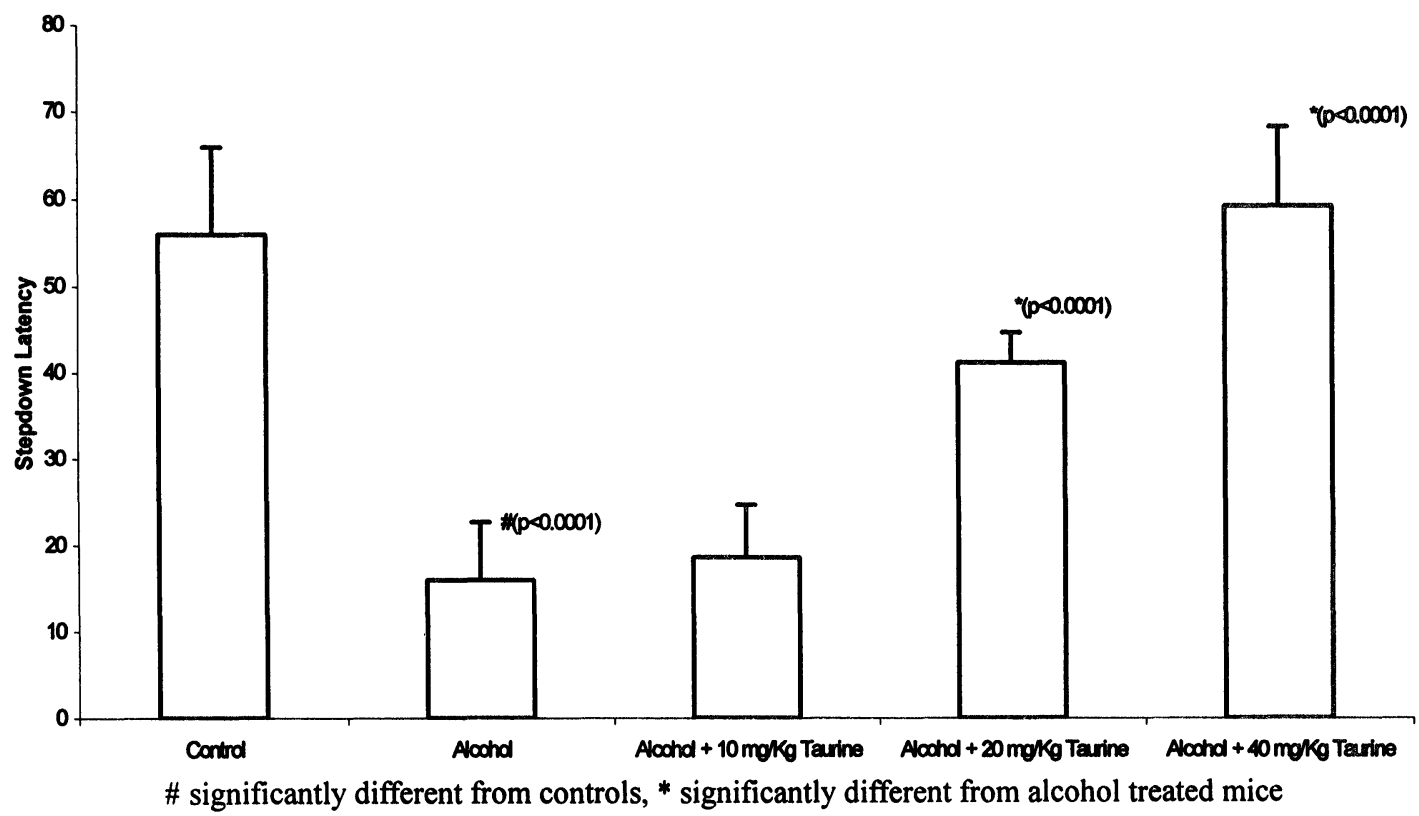

Fig. 13: Effect of 10 days of taurine treatment on stepdown latency in alcohol-treated mice 


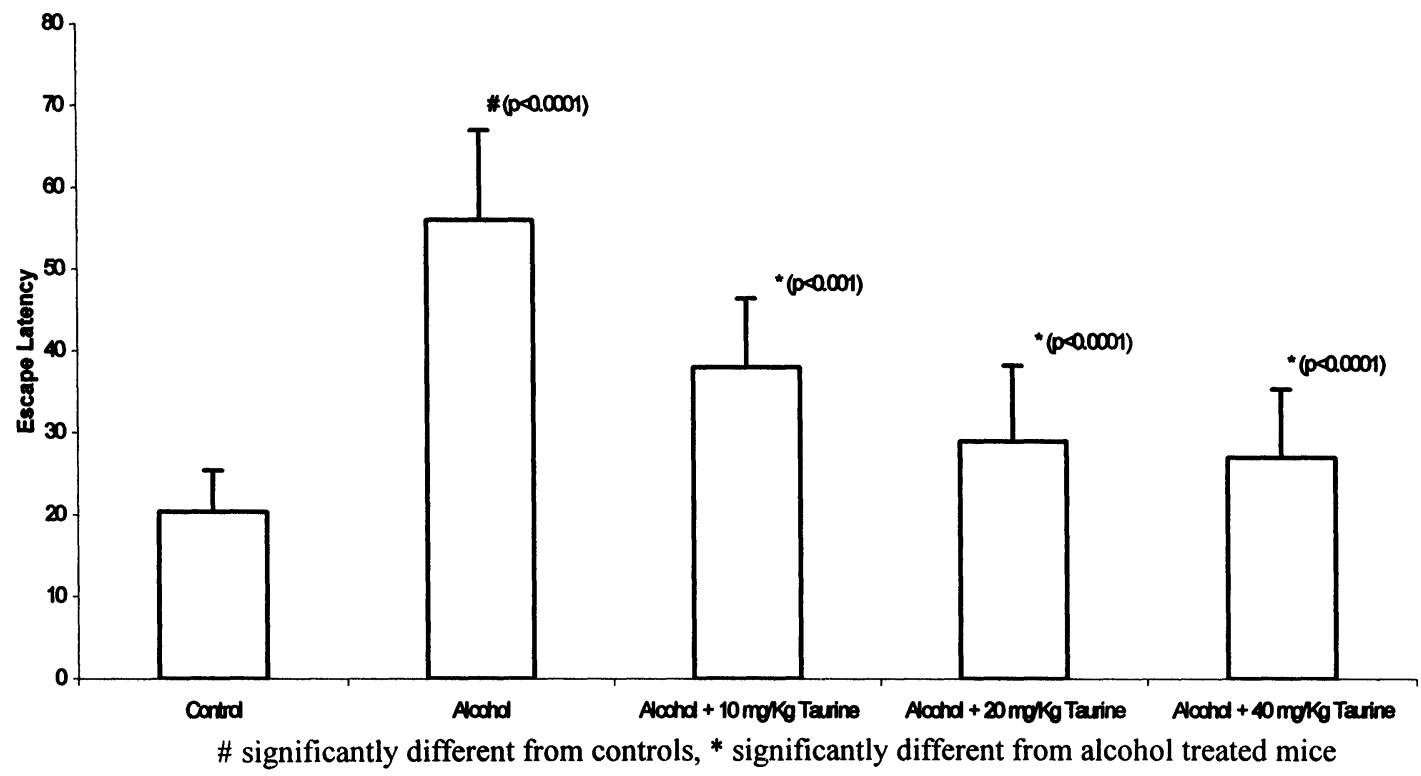

Fig. 14: Effect of 10 days of taurine treatment on escape latency in alcohol-treated mice

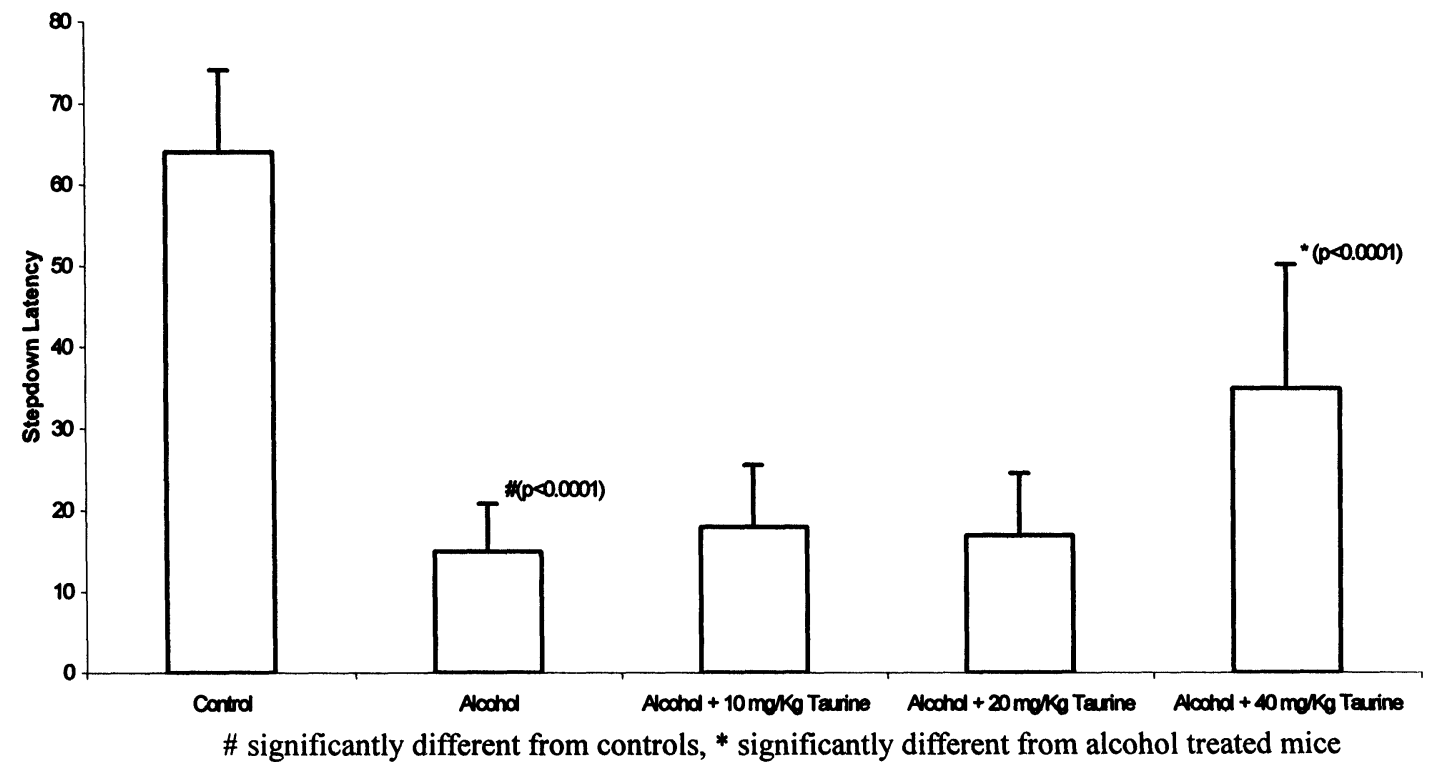

Fig. 15: Effect of 30 days of taurine treatment on stepdown latency in alcohol-treated mice 


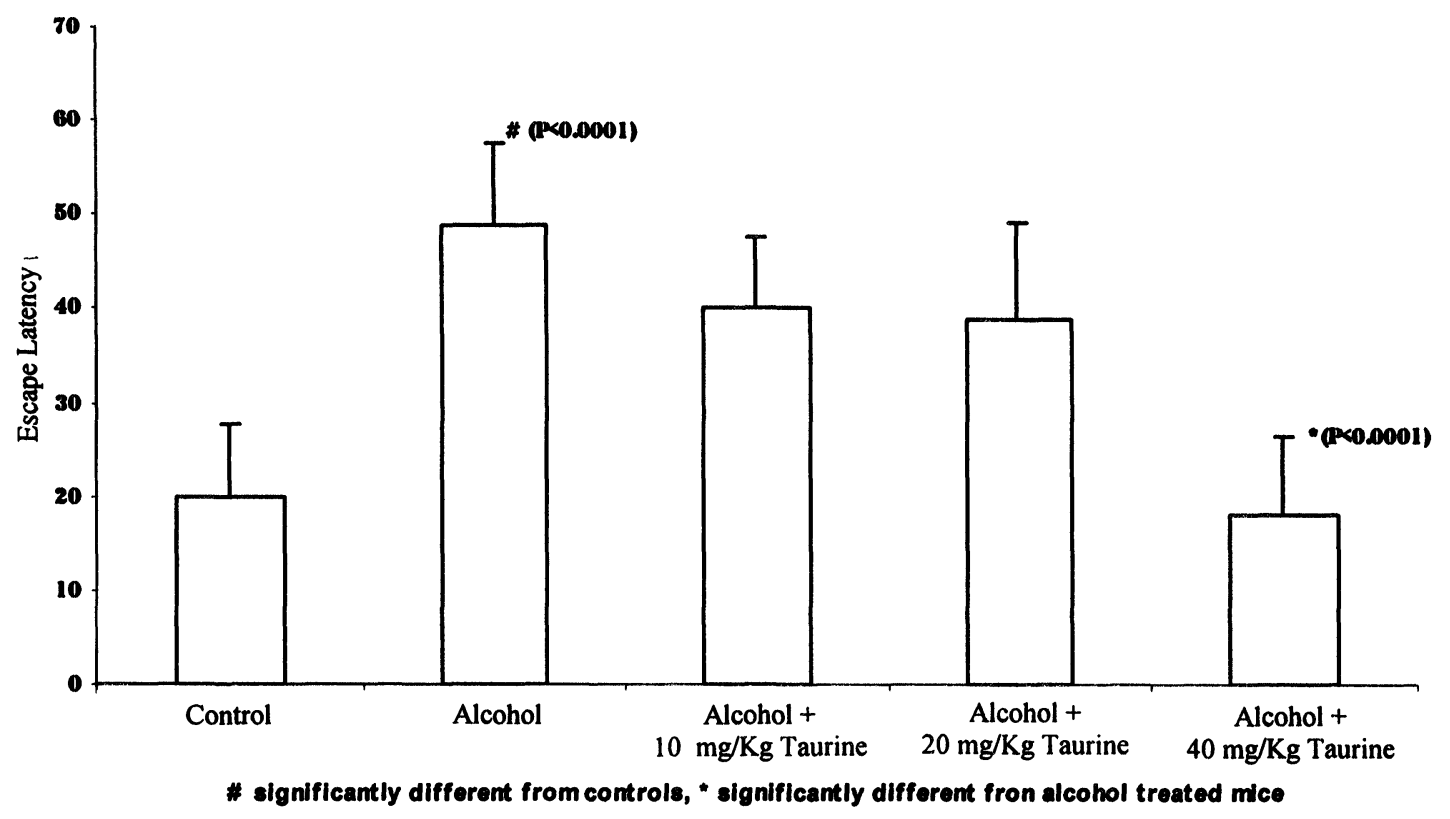

Fig. 16: Effect of 30 days of taurine treatment on escape latency in alcohol-treated mice

\section{DISCUSSION}

Learning and memory processes represent the plasticity of the nervous system (Rose, 1995). This enables us to understand the mechanism of the adaptation of the brain both at the cellular and at the molecular levels. Thus, brain plasticity enables the organism to adapt to environmental changes, but this plasticity is altered during various types of environmental and chemical insults. The changes in normal behavior and memory processes after amnesia-inducing treatments are its best examples.

In the present study, taurine did not show any effect on the escape latency or the step down latency of mice. The only two reports that have been published so far on the effects of taurine have contradictory results. In one study by Sanberg and Fibiger (1979), chronic treatment with taurine altered the impairment of acquisition and to a lesser extent, of retention of a step down passive avoidance task in rats. But in that study, taurine was administered orally $(0.9 \%)$ in drinking water. With such methods, determining the intake of the drug (because the drinking capacity of different animals may vary) and the dose-dependent effect of taurine in the memory process is difficult. In the other study by Rivas-Arancibia et al. (2000), taurine did not show any effect in young and mature rats, but it was helpful in improving memory in old rats. In that study, the effect of only one taurine treatment of $43 \mathrm{mg} / \mathrm{kg}$ was determined.

The present study is unique in the sense that three different doses of taurine were studied for two time durations. Moreover, in earlier studies on the effects of taurine on memory function, synthetic taurine was used. In the present study, 
we used natural taurine extracted from Pegasus laternarius Cuvier, which has been used as a traditional cure for senile disorders in China.

Taurine, by itself, did not show any effect on memory in the present study but was quite effective in protecting the animals from the amnesia produced by various amnesia-inducing agents. Oxidative stress plays an important role in memory deterioration (Larney et al., 1995). Taurine has been found to protect the neuron from toxicity induced by glutamate and kainic acid (Huxtable, 1992), which have been known to produce oxidative stress on muscarine cholinergic receptors. The protective action of taurine may involve a similar mechanism in various types of stressful conditions like the chemical insults to which the animals were exposed in the present investigation. Along with this, taurine also acts as a potent antioxidant. Taurine interacts with barbiturate binding sites in the central nervous system, which may be one possible reason for its protection against the amnesia produced by pentobarbital. Cycloheximide and sodium nitrite are considered inhibitors of protein synthesis that are known to cause amnesia. In the cycloheximide and sodium nitrite groups, a lower SDL and higher EL were found when compared with taurine-treated groups. This result demonstrates the inhibitory effect of taurine on the action of cycloheximide or sodium nitrite.

Ethyl alcohol can cause severe memory deficiency (Goldberg, 1993). Although the mechanism is not clear, ethanol has been found to affect selectively several functional processes that are related to learning and memory in the central nervous system. Ethanol affects both the central cholinergic and adernergic systems (Carlson et al., 1973, Signs et al., 1987). In the present study, ethanol showed a significant influence on motor coordination. The results agree with those of Hornykiewicz (1979) and Claudio \& Roberta, (1990). The present study has shown that the impaired memory and motor coordination induced by ethanol was successfully averted by taurine $(40 \mathrm{mg} / \mathrm{kg})$. In addition to this effect, taurine can directly detoxify alcohol (Kerai et al., 1998). Thus, taurine plays an important role in overcoming the amnesia produced by various chemical agents and thereby helps in maintaining the homeostasis in the brain when under chemical insults. Also, taurine does not interrupt normal behavioral functions when exerting its effects on the memory functions of the brain.

\section{ACKNOWLEDGMENTS}

The authors are thankful to Tiang Loong for technical assistance. We are also grateful to Jason Groshong of Department of Neurology, University of Minnesota, USA, for editing the manuscript.

\section{REFERENCES}

Balazs M, Telegdy G. Effects of glutaurine treatment on electroshock-induced amnesia. Antiamnesic action of glutaurine. Neuropeptides 1988; 12 : 5558.

Carlson A, Engel J, Svensson TH. Inhibition of ethanol-induced excitation in mice and rats by $\alpha$ methyl- $\beta$-tyrosine. Psychopharmacology 1972; 26: 307-312.

Ceballos I., Javoy-Agid F, Delacourte, A., DeFossez, A., Nicole, A., Sinet, P. Parkinson's disease and Alzheimer's disease: Neurodegenerative disorders due to brain antioxidant system deficiency. In: Emert I, ed, Antioxidants in Therapy and Preventive Medicine. New York, NY, USA: Plenum Press, 1990; 493--498.

Ghelardini C, Galeotti N, Bartolini A. Influence of potassium channel modulation on cognitive process in mice. $\mathrm{Br} \mathrm{J}$ Pharmacol 1998; 123: 1079-1084.

Goldberg L. Quantitative studies on alcohol tolerance in man. Acta Physiol Scand Suppl 1993; 5:1-128.

Hornykiewicz O. Brain dopamine in Parkinson's disease and other neurological disturbances. In: 
Horn AS, Korf J, Westerink BHC, eds, The Neurobiology of Dopamine. New York, NY, USA: Academic Press, 1979; 663-664.

Huxtable RJ. Taurine in the central nervous system and the mammalian actions of taurine. Prog Neurobiol 1989; 32: 471-533.

Huxtable RJ. Physiological actions of taurine. Physiol Rev 1992; 72: 101-163.

Kerai MD, Waterfield CJ, Kenyon SH, Asker DS, Timbrell JA. Taurine: Protective properties against ethanol-induced hepatic steatosis and lipid peroxidation during chronic ethanol consumption in rats. Amino Acids 1998; 15: 53-76.

Liljequist R, Winblad B. Guanidinoethanesulphonic acid facilitates retention of spatial memory in old rats. Pharmacol Toxicol 1993; 73:186-188.

Magnusson KR. Distribution of taurine, glutamate, and glutamate receptors during postnatal development and plasticity in the rat brain. In: Huxtable RJ et al., eds, Taurine, Vol. 2. New York/London: Plenum, 1996; 435-444.

Man'Kovs'Ka IM, Seredenko MM, Vavilova HL, Kharlamova OM, Bystriuko VO. The antioxidant action of taurine in acute hypoxic hypoxia. Fiziol Zh 1998; 44: 65-72.

Michiels C, Raes M, Toussaint O, Remacle J. Importance of Se-glutathione peroxidase, catalase and $\mathrm{Cu}-\mathrm{Zn}$ SOD for cell survival against oxidative stress. Free Radic Biol Med 1994; 17: 235-248.

Montanini R, Gasco P. Taurine in the treatment of diffuse cerebral arteriopathies. Clinical and electroencephalographic observations and psychological tests. Clin Ter 1974; 71: 427-436.

Rivas-Arancibia S, Dorado-Martinez C, Borgonio-
Perez G, Hiriart-Urdanivia M, Verdugo-Diaz L, Duran-Vazquez A, et al. Effects of taurine on ozone induced memory deficits and lipid peroxidation levels in brains of young, mature and old rats. Environ Res 2000; 82: 7-17.

Rose SPR. Glucoproteins and memory formation. Behav Brain Res 1995; 66: 73-78.

Sanberg PR, Fibiger HC. Impaired acquisition and retention of a passive avoidance response after chronic ingestion of taurine. Psychopharmacology (Berl) 1972; 62: 97-99.

Saransaari P, Oja SS. Phencyclidine-binding sites in mouse cerebral cortex during development and ageing: Effects of inhibitory amino acids. Mech Ageing Dev 1993; 68: 125-136.

Signs SA, Yamamoto BK, Schechter MD. In vivo electrochemical determination of extracellular dopamine in the caudate of freely moving rats after a low dose of ethanol. Neuropharmacology 1987; 26: 1653-1656.

Son M, Ko JI, Kim WB, Kang HK.and Kim BK. Taurine can ameliorate inflammatory bowel disease in rats. Adv Exp Med Biol 1998; 442: 291-298.

Tsuji A, and Tamai I. Sodium and chloride dependent transport of taurine at the blood brain barrier. In: Huxtable et al., eds, Taurine, Vol. 2. New York/ London: Plenum, 1996; 385-391.

You JS, Chang KJ. Taurine protects the liver against lipid peroxidation and membrane disintegration during rat hepatocarcinogenesis. Adv Exp Med Biol 1998; 442: 105-112.

Zhu X. Improvement of impaired memory in mice by huperzine A and Huperzine B. Acta Pharmacol. Sinica 1988; 9: 492-497. 

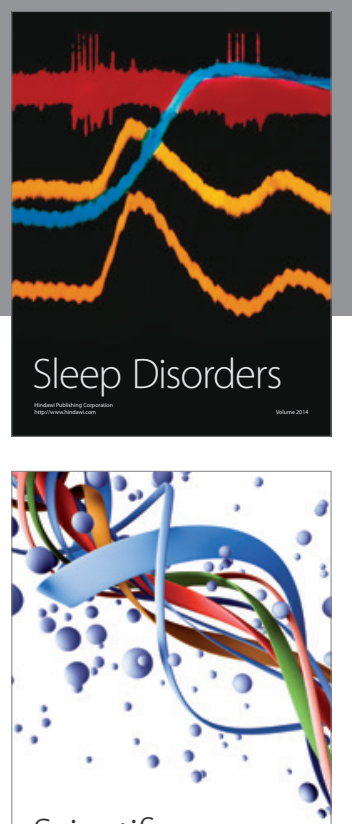

Scientifica
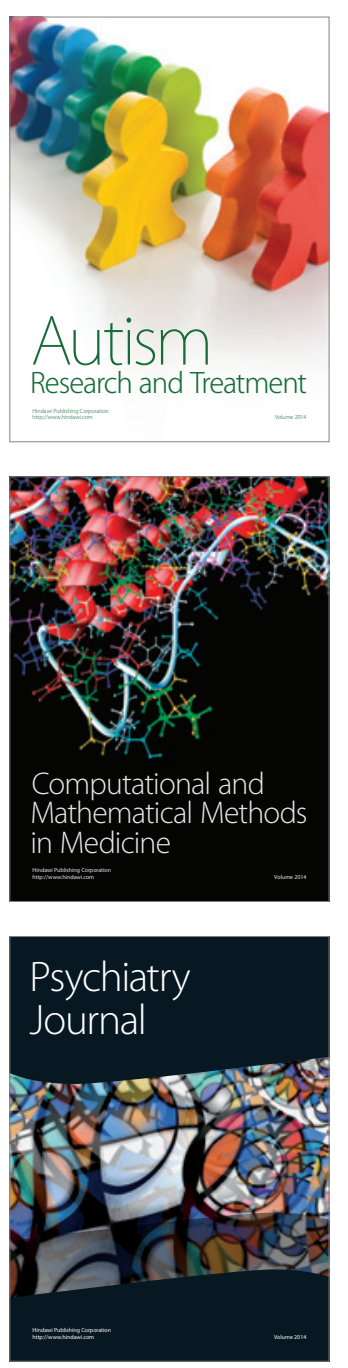
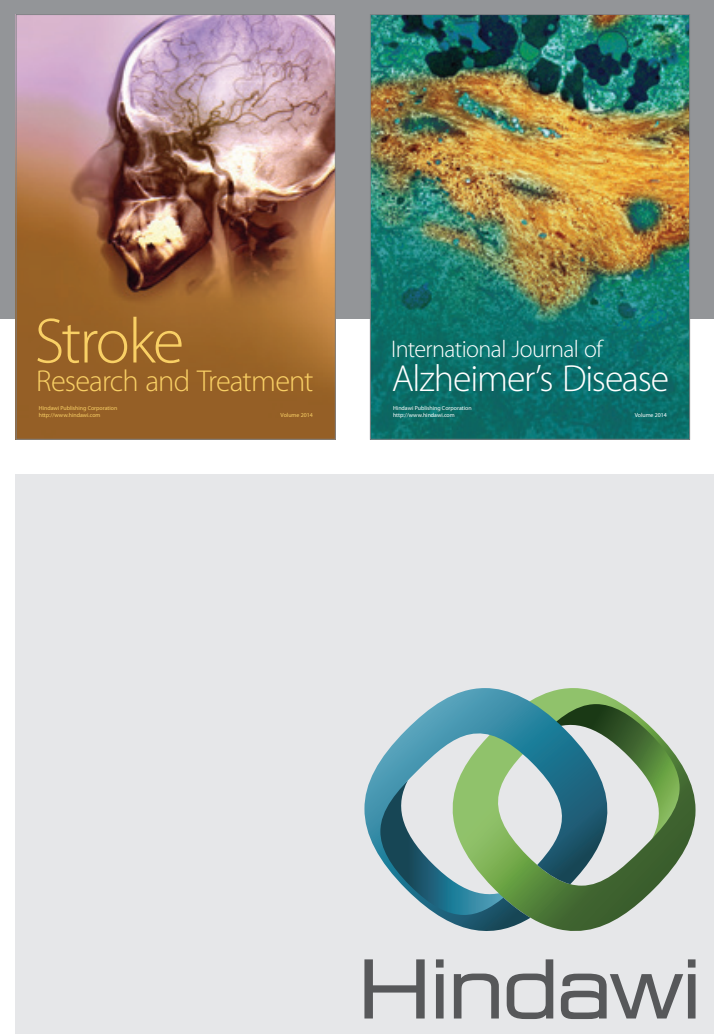

Submit your manuscripts at

http://www.hindawi.com
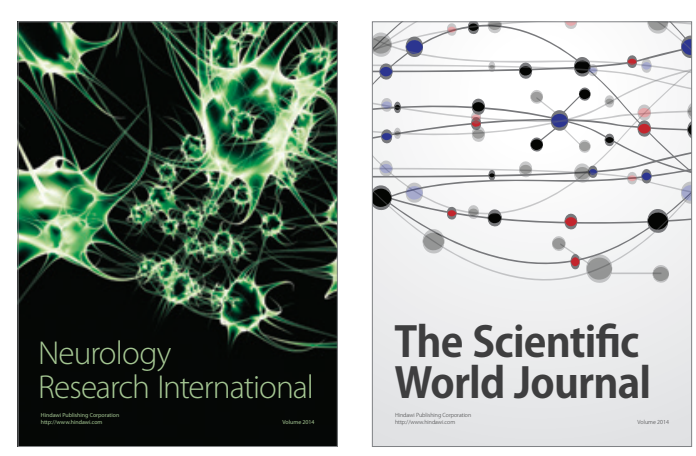

The Scientific World Journal

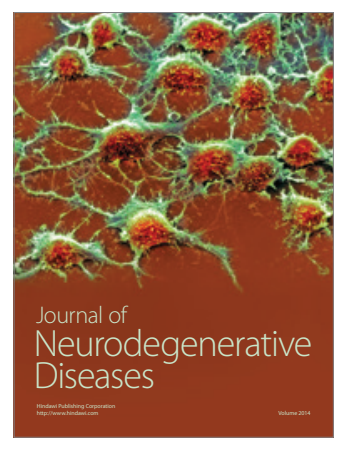

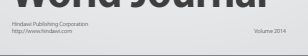

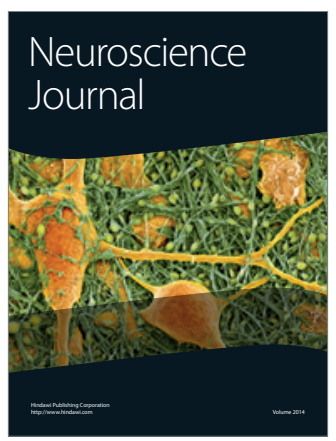

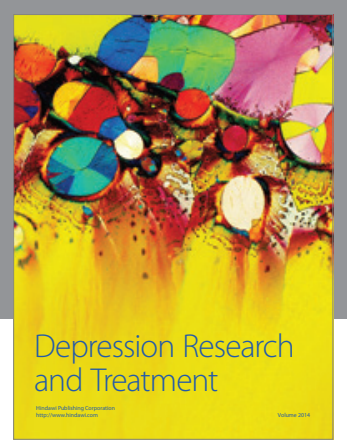
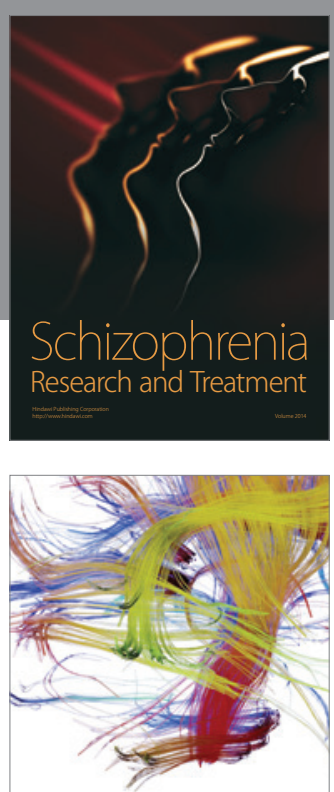

Brain Science

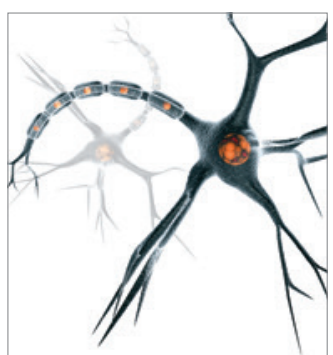

Neural Plasticity
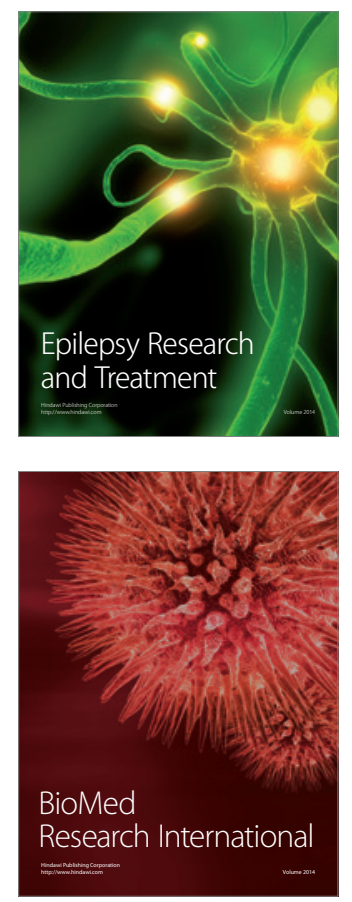

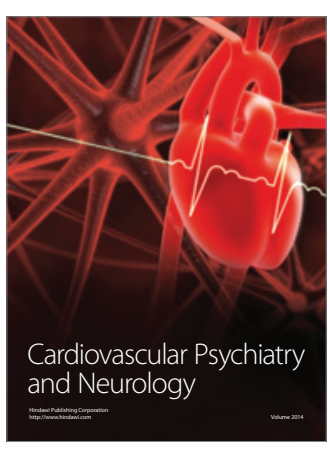

Parkinson's

Disease
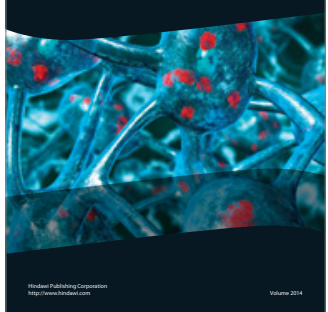